\title{
Política de avaliação da pós-graduação e suas consequências no trabalho docente
}

\author{
Wercy Rodrigues Costa Júnior \\ Mariluce Bittar ${ }^{* *}$
}

\section{Resumo}

Neste artigo, investigam-se as políticas de avaliaçáo da pós-graduaçáo e suas consequências no trabalho dos pesquisadores. A pesquisa fundamentou-se na abordagem qualitativa, incluindo a análise histórica e realizaçáo de entrevistas com professores dos Programas de Pós-Graduação em Educação da Universidade Federal do Mato Grosso do Sul (UFMS) e da Universidade Católica Dom Bosco (UCDB). Os resultados indicam que as atuais políticas para a educaçáo superior do país se encontram inseridas nessa estratégia de inclusão da economia brasileira às intensas mudanças que ocorrem na base produtiva do capitalismo em nível global, atingindo as políticas públicas para a pós-graduaçáo. As mudanças no mundo do trabalho tiveram um impacto significativo marcado pela negatividade na natureza do trabalho docente da pós-graduaçáo.

Palavras-chave: Tendências da Política Educacional. Avaliação da Pós-Graduaçáo. Condiçóes do Trabalho Docente.

* Mestre em Educaçáo pela Universidade Católica Dom Bosco (UCDB). Coordenador e professor de Filosofia na UCDB.

** Doutora em Educaçáo - Universidade Federal de Sáo Carlos (UFSCar). Professora do Programa de Pós-graduaçáo em Educaçáo da Universidade Católica Dom Bosco (UCDB). Coordenadora do Grupo de Estudos e Pesquisas Políticas de Educaçáo Superior (GEPPES). Editora da Série-Estudos. 


\section{Introdução}

Este artigo investiga as políticas de avaliaçáo da pós-graduaçáo em educaçáo, implementadas pela Coordenaçáo de Aperfeiçoamento de Pessoal de Nível Superior (CAPES) e suas consequências no trabalho docente. Para tanto, identifica a articulaçáo entre a avaliaçáo na pós-graduaçáo, a reestruturaçáo do sistema capitalista e o trabalho docente na pós-graduaçáo, situando-a no triênio 2004-2006.

Esta discussão, que se iniciou em meados da década de 1960, teve um de seus ápices no ano de 2005 quando se completaram os 40 anos de implantaçáo desse nível de ensino no Brasil, comemorado, inclusive, como tema geral na $28^{a}$ Reunião Anual da Associação Nacional de Pós-Graduação e Pesquisa em Educação (ANPEd) (2005): "40 anos da Pós-Graduaçáo em Educaçáo no Brasil”, que aconteceu em Caxambú/MG.

Para Alves (2008), foi a nova sistemática de avaliaçáo implementada pela CAPES que desencadeou as discussóes acerca do tema na última década, especialmente após resultados do biênio 1996-1997, incitando os programas de pós-graduaçáo stricto sensu a mudar o seu foco para a formaçáo de pesquisadores e, aos poucos, inserindo o trabalho docente, sob a égide da produtividade.

É nesse contexto que se desenvolve esta pesquisa, contemplando dois Programas de Pós-Graduaçáo em Educaçáo de Mato Grosso do Sul: o Programa de Pós-Graduaçáo em Educaçáo da Universidade Católica Dom Bosco (UCDB) ${ }^{1}$ e o Programa de Pós-Graduaçáo em Educaçáo da Universidade Federal de Mato Grosso do Sul (UFMS) ${ }^{2}$. Foram selecionados docentes de cada Programa para serem entrevistados, considerando os seguintes critérios:

- que trabalhassem como docentes na pós-graduação stricto sensu há pelo menos cinco anos, de tal forma que tivessem passado por pelo menos um triênio de avaliaçáo da CAPES;

- que tivessem trabalhado na pós-graduaçáo antes da implantação do modelo de avaliaçáo da CAPES, principalmente o introduzido no final dos anos 1990.

Foram entrevistados também professores que iniciaram suas atividades tendo como referencial de avaliaçáo o modelo vigente, aquele utilizado no Triênio de Avaliaçáo da CAPES, 2004-2006. Três docentes de cada programa atenderam a esses critérios. 
Importa ressaltar que esta pesquisa realizou-se no âmbito dos estudos desenvolvidos pelo Grupo de Estudos e Pesquisas Políticas de Educaçáo Superior (GEPPES) vinculada à Linha de Pesquisa: Política Educacional, Gestão da Escola e Formação Docente, do Programa de Pós-Graduaçáo em Educaçáo Mestrado e Doutorado, da UCDB.

\section{A centralidade do trabalho no processo de emancipação humana}

O trabalho é a base de uma comunidade humana, porque permite que os seres humanos estabeleçam as mais variadas relaçôes: sociais, linguísticas, axiológicas etc. Ele é a origem e o fundamento do desenvolvimento da humanidade, pois se relaciona à história dos meios de produçáo e das relaçóes de produçáo, como propóe a concepçáo materialista da história. Nesse sentido, o trabalho pode ser considerado como a forma originária do mundo dos seres humanos, como fenômeno originário, como modelo do ser social. (LUKÁCS, 1979). Ou seja, como a protoforma na qual se assenta o mundo dos homens e das mulheres.

É intrínseca ao ser humano a sua predisposiçáo à vida em sociedade, sendo o trabalho o seu fundamento. Para Engels (1999), o trabalho é a possibilidade concreta que permitiu a passagem de um animal, predisposto geneticamente, à humanidade. Somente por meio do trabalho "[...] o homem pode passar da generalidade do seu ser-em-si para a generalidade do ser-para-si, por se configurar o trabalho como meio de expressão e de realização da essência necessária do homem, sua humanidade." (INFRANCA, 2005, p. 12, traduçáo nossa).

Tratando do trabalho na sua totalidade, é necessário entender que só há trabalho quando este faz parte do processo de reproduçáo social, ou seja, somente no ser social existe trabalho. Portanto, "[...] isolado da totalidade social, enquanto absoluta singularidade que náo participa da sociedade, o trabalho sequer existe enquanto tal.” (LUKÁCS, 1972, p. 76). É a funçáo social dos atos que os fazem ou náo ser trabalho, ainda que a singularidade de cada trabalho náo seja impugnada em detrimento da necessária participaçáo do trabalho na totalidade social.

Nessa perspectiva, o professor PP33 , referindo-se ao trabalho docente na pós-graduação, afirma que a finalidade da "Produçáo acadêmica é a sua tradução 
em políticas públicas que favoreçam a população". Portanto, um ato singular que tem implicaçóes na totalidade social. $\mathrm{O}$ trabalho é sempre e necessariamente um ato humano, marcado pela singularidade. E, assim como é impossível anular a conexão do trabalho com a totalidade social, também é impossível ocultar a sua singularidade, mesmo que parta de uma decisáo de repetir o já realizado.

Destarte, diferentemente do que ocorre na esfera biológica, essa transformaçáo da natureza é teleologicamente posta. O trabalho, na sua forma exclusivamente humana, caracteriza-se, também, por sua dimensáo teleológica. Isto é, o trabalho humano caracteriza-se pela antecipaçáo mental do resultado que é previamente construído na subjetividade sob a forma de uma finalidade que orientará todas as açóes que virão a seguir (MARX, 1985). $\mathrm{O}$ ser consciente constitui historicamente a natureza humana; a satisfaçáo das necessidades do indivíduo é o fim, o resultado e o objetivo do trabalho humano. Essa transformaçáo teleologicamente posta da natureza é que se denomina de trabalho. E como as necessidades mudam historicamente, as formas históricas de trabalho humano, para satisfazer essas necessidades, também mudam.

Portanto, o trabalho é a marca humana mais decisiva por ser a condiçáo de possibilidade de o ser humano construir um futuro respondendo conscientemente às necessidades percebidas e identificadas em sua cotidianidade. A originalidade da natureza humana se funda na sua capacidade de constituir-se consciente na relaçáo com a natureza.

Esse fenômeno, na afirmação da professora PP1, "É o pano de fundo, é uma questáo continuamente presente no trabalho docente na pós-graduação".

A consciência, nesse sentido, estrutura o agir humano revelando o ser humano como um ser autocriativo que constrói a realidade humana e social pela práxis. Para Kosik (1989), por práxis entende-se a determinaçáo da existência humana como elaboraçáo da realidade "[...] e a possibilidade de transformaçáo". A práxis se articula essencialmente ao homem, em todas as suas manifestaçóes, pois ela é maneira específica de ser do indivíduo.

A universalidade da práxis, marcada pela capacidade de o ser humano criar a realidade, que é humana e social, e de compreendê-la, revela que o indivíduo é um ser ontocriativo. Ainda segundo Kosik (1989), no conceito de práxis encontram-se o movimento laborativo e o existencial como dois momentos de um único movimento. No movimento existencial, a singularidade humana se produz e se expressa nas relaçóes. Para se autorrealizarem, as pessoas exteriorizam 
a sua interioridade colocando-se em sua obra. Isto é, a objetividade revela o caráter intersubjetivo da expressáo do homem. Já o movimento laborativo manifesta a inserçáo do indivíduo no mundo por meio da sua produçáo ativa. A natureza humana aqui se expressa como trabalho, pois o homem vê-se a si mesmo no mundo por ele construído.

Essa identificaçáo com o mundo e com o objeto produzido conduz, necessariamente, a um sentimento de prazer e realizaçáo, como assegura a professora PP1, ao analisar o seu trabalho:

O nosso jeito de pensar a pós-graduaçáo e isso foi uma experiência muito positiva. Esse periodo em que eu trabalhei aqui, esse processo de crescimento do Programa, o que a gente pode chamar de "trajetória bem-sucedida", no sentido da sua avaliação que foi em um crescendo... Eu me sinto parte desse movimento e, entáo, para mim, tem o sentido de realizaçáo pessoal estar/ser professor aqui neste Programa.

Toda objetivaçáo resulta em novos conhecimentos e novas habilidades, em novas possibilidades, e por isso, ao transformar a natureza, o indivíduo também se transforma. Nessa exata medida, a produçáo do objeto náo é apenas o processo de objetivação; não é apenas uma transformaçáo da realidade, mas é também a exteriorizaçáo de um sujeito. Cada uma das transformaçóes do real ocorrerá no nível de desenvolvimento alcançado pela individualidade em questáo.

O trabalho é o meio de exteriorização da essência necessária do ser humano, enquanto realiza a universalidade do gênero humano: a humanidade. $\mathrm{O}$ ser humano se revela e transpassa no objeto produzido. $\mathrm{O}$ produto do seu trabalho já não é um em-si, mas um para-si. É possível que o ser humano reconheça-se nos produtos que criou (VÁZQUEZ, 1977). Assim, a obra mesma do ser humano, o trabalho e seu produto mais autêntico, o ser social, marcam a dimensáo originária do indivíduo. Por isso, o trabalho é um dos elementos constitutivos do ser humano e a sua realizaçáo se transforma em fonte de prazer, como assegura o professor PP3, referindo-se ao seu trabalho na pós-graduaçáo: "Tenho conseguido articular de uma forma bastante satisfatória para mim, de tal forma que trabalho com muito gosto".

Assim, como princípio do ser humano individual e social, “[...] é ainda mais princípio do homem como ser histórico: o ser humano com o trabalho colocou em movimento uma série causal que teve como primeira consequência 
a passagem do animal ao humano." (INFRANCA, 2005, p. 32, tradução nossa). Nessa perspectiva, podemos ousar e afirmar que o indivíduo foi criado pelo trabalho, "[...] enquanto este se manifesta como a primeira condiçáo fundamental de toda vida humana" (ENGELS, 1999, p. 4). Homens e mulheres são, em certa medida, criados pelo trabalho, pois é justamente o trabalho, isto é, a possibilidade de mudar as coisas, de transformar o mundo e de fazer objetos, que vai diferenciá-los, fundamentalmente, do animal.

Por isso, o trabalho é uma categoria essencial para se compreender a história do ser humano. Por meio do trabalho, cada homem constrói a sua história enquanto produz a sua própria existência, ainda que o desenvolvimento das forças produtivas num determinado momento histórico a condicione.

O processo de produçáo e reproduçáo da realidade/humanidade/ sociedade deve ser considerado desde a realizaçáo histórica do trabalho, pois é nela que os homens fazem a sua própria história, náo em condiçóes por eles escolhidas e, tampouco, de maneira arbitrária, mas em circunstâncias que encontram imediatamente diante de si, determinadas pelos fatos e pela tradiçáo, historicamente. (LUKÁCS, 1972). Na história o homem realiza-se a si mesmo.

Antes da história e independente dela, o ser humano náo sabe quem é, náo possui uma identidade. Ainda para Kosik (1989), somente na história o homem existe. $\mathrm{O}$ explicitamento do indivíduo a si mesmo na história, que equivale à criaçáo do homem e da humanidade/sociedade, é o sentido da própria história. A história, nesse sentido, apresenta-se como a substância da sociedade. E a substância contém em si a permanência da heterogeneidade de toda estrutura social, por isso a substância da sociedade só pode ser a própria história. (HELLER, 1970).

A história dos homens revela precisamente o fim, teleologicamente falando, da açáo dos homens em sociedade. A humanidade é a única responsável por seu destino. Os homens náo cumprem um dado destino imposto por forças ou determinaçóes que náo podem controlar. Por isso, a relaçáo dos indivíduos em sociedade com a história está determinada pelo desenvolvimento da sua capacidade de fazer história. Esta, por sua vez, está intimamente vinculada à capacidade de os homens em sociedade extraírem da natureza os meios necessários à sua reproduçáo social, garantindo a reproduçáo biológica dos indivíduos que a compóem. A história está, desse modo, intrinsecamente vinculada ao desenvolvimento das forças produtivas. À medida que as forças 
produtivas se desenvolvem, alarga-se o horizonte de possibilidades para os homens fazerem sua história.

No entanto, o processo histórico no qual estamos inseridos nesse período de transiçáo do século XX para o XXI apresenta uma característica paradoxal. Por um lado, a história parece querer nos apontar para a efemeridade e a fugacidade de todas as coisas. $\mathrm{O}$ que ontem era referência segura para pautar nossos comportamentos, hoje se manifesta inconsistente. Todas as dimensóes da vida humana se encontram afetadas pela pressáo esmagadora da efemeridade.

Todavia, essa percepçáo de que nada permanece por muito tempo convive com outra percepçáo que nos leva a crer no "[...] extremo oposto: que tudo permanece o mesmo. Como se esse mesmo período histórico, com sua permanente fluidez, tivesse uma única função: convencer-nos da insuperabilidade do mercado" (LESSA, 2005, p. 70). Todas as transformaçóes ocorrem justamente para obedecer às necessidades do mercado, ainda que superfluamente estejam revestidas da intenção de se voltar contra ele. As mudanças revelam a permanência e a insuperabilidade do mercado. A mercadoria, assim, nesse mundo em constante mudança, é a única realidade que permanece. Esse fenômeno, como afirma a professora PP1, encontra-se profundamente implicado no trabalho docente na pós-graduaçáo. De acordo com suas palavras:

Espera-se que o resultado da pesquisa se transforme rapidamente em produto. Essa é uma das razóes da tal pressāo, do stress. Esse é um dos embates da pós-graduação com os órgáos de avaliação, pela intensa cobrança de produtividade, num ritmo em que tudo tem que gerar produto, mercadoria.

De um mundo em constante transformação como o nosso, o que se deveria esperar era que todos os indivíduos chegassem à conclusão acerca da eterna efemeridade de todas as coisas, uma vez que tudo está se transformando. No entanto, "o exato oposto tem lugar: nada a se fazer senáo aceitar as transformaçóes que vivemos como a evidência cabal de que, seja qual for o futuro, será sempre regido pela mercadoria, pelo mercado" (LESSA, 2005, p. 71).

A mundivisáo burguesa é capaz de rebaixar a nossa existência a uma dimensão de imediaticidade e presentificação, sem levar em consideraçáo o 
passado, o presente e o futuro como determinaçóes reais e materiais da nossa existência.

Perdida a conexáo com a sua historicidade, o indivíduo - portador de uma racionalidade afetada - acaba perdendo-se e esvaziando-se na sua relaçáo consigo mesmo e com a sociedade, uma vez que a sua individualidade foi dissolvida em uma totalidade carente de mediaçóes. A história construída socialmente torna-se estranha, "não nos reconhecemos nas consequências dos nossos atos, náo nos reconhecemos nas consequências do que nós próprios provocamos a nós mesmos" (LESSA, 2005, p. 73). Torna-se impossível elaborar uma síntese pessoal por ficarmos perdidos nas dimensóes globais da nossa interioridade.

Ao fazer do trabalho e da força de trabalho uma mercadoria igual às demais, separando-o do seu produto, o modo de produçáo capitalista, regido pela lógica de mercado, acaba produzindo novas formas de relaçóes sociais, escondendo que se trata de relaçóes entre pessoas. A produçáo destrutiva de mercadorias é, necessariamente, a reprodução destrutiva de nossa humanidade (LESSA, 2005, p. 74). A mercadoria materializa as relaçóes sociais, aparecendo nelas como dotada de poder próprio. Como observa Pessanha (1995), esse processo de reificaçáo, ao produzir o fetiche da mercadoria é o fundamento da alienaçáo do mundo moderno. $\mathrm{O}$ trabalhador náo se reconhece na mercadoria que produz, tornando-se mero mediador entre o instrumento que usa e o produto que gera tornando-se ele mesmo mercadoria.

\section{Processo de trabalho docente na pós-graduação na perspectiva dos professores pesquisadores}

O trabalho docente na pós-graduaçáo está fundamentado no ensino, na pesquisa, orientaçáo e, em alguns casos, nas atividades de extensáo. Contudo, ele é cobrado e exigido para além dessas atividades, como expressa a professora PP1, quando afirma que:

O trabalho do professor na pós-graduação envolve todas essas situaçōes. Necessariamente, o professor hoje, na pósgraduaçâo, é cobrado além da atividade de docência. Ele deve ministrar aulas e, dentro de cada programa, pelo menos uma vez por ano, ele deve oferecer sua disciplina. Ele tem que ter orientaçáo; nos Programas a gente tem um limite de oito orientandos para cada orientador; muitas vezes esse 
limite é ultrapassado e isso, vamos dizer, não é bem visto pelos órgáos de avaliação, mas muitas vezes as exigências do Programa acabam determinando que isso aconteça. Muitas vezes o professor tem orientaçáo aqui e orientaçáo fora, em outra instituição. Então, docência e orientação são centrais nos encargos dos docentes da Pós.

O "tripé" formado pelo ensino, pela pesquisa e pela extensão constitui, segundo o artigo 207 da Constituiçáo brasileira ${ }^{4}$ (BRASIL, 1988, p. 136), o eixo fundamental da universidade brasileira e, por conseguinte, a razáo de ser da pós-graduação, que obedece ao princípio da indissociabilidade. Comentando esse assunto, a professora PB2 se posiciona afirmando que, para descrever o processo, ela pode:

Separar em três momentos que sáo interligados: a docência especificamente, que são aulas, que inclui as disciplinas que eu ministro na pós-graduação; eu tenho fundamentalmente uma disciplina comum no Doutorado [...] E basicamente é estudar para me preparar, principalmente no Doutorado. No Doutorado eu costumo dizer que nós náo preparamos aula, nós nos preparamos para a aula, porque você não sabe o que é...

A indissociabilidade apresenta-se como o princípio que orienta a qualidade da produçáo, por definir como fundamental e necessária a tridimencionalidade da universidade Superior. Porém, essas três expressóes referem-se às atividades - e náo aos objetivos - por meio das quais a universidade procura objetivar suas funçóes e atribuiçóes na sociedade.

Referindo-se exclusivamente à dimensão do ensino, PP2 relata que na pós:

Você tem que oferecer uma disciplina pelo menos uma vez a cada três anos, essa que é a regra. Então, aqui como nós somos poucos a gente ministra aula... Está bem dividido, por exemplo, o curso tem quinze encontros, entáo eu dou cinco aulas, a outra dá cinco, entáo náo é tão pesado.

Ainda que esteja tratando do tema do ensino, no final de sua exposiçáo o professor ressalta o caráter indissociável do ensino e da pesquisa ao terminar afirmando que: "Depois tem o trabalho de pesquisa, que dai é assim: a pesquisa 
individual ou pesquisa coletiva, às vezes tem as duas, tem um grupo de pesquisa, tem as reuniöes das atividades do grupo de pesquisa".

A pós-graduaçáo, como se revelou na concepçáo dos professores entrevistados, atribui centralidade ao processo de pesquisa, revelando-a como lugar substantivo de produçáo do conhecimento. Por isso, na pós-graduaçáo é imprescindível a construçáo de práticas investigativas, uma vez que a prática sistematizadora da investigaçáo científica encontra nela o seu ethos natural, dado que a própria pesquisa é sua atividade específica. Esse caráter de primazia é reforçado pela professora PB2 quando revela sua concepçáo de pós-graduaçáo: "Ser pesquisadora, na concepção que eu tenho de curso de pós-graduaçáo, é essencial para que eu possa fazer as outras".

Assim, a realizaçáo de uma pesquisa científica é objetivo fundamental dos pós-graduandos, pois a pesquisa deve ser situada no âmago do investimento acadêmico exigido pela pós-graduação. Nesse sentido, continua a professora: "A gente se prepara para a aula. Isso me toma muito tempo porque eu náo apenas releio as leituras que eu recomendo para os alunos, todas, como leio outras em relação a isso, ressalta o professor".

É, doravante, a produçáo do conhecimento por meio da pesquisa, articulada à formaçáo de novos pesquisadores, a justificativa substantiva que fundamenta a razáo da existência da pós-graduaçáo. Isso impóe à pósgraduaçáo a necessidade de "fundamentação teórica, de reflexão sistemática, de levantamento de dados empíricos, documentais ou históricos" (SEVERINO, 2009, p. 16), que permitam o desvelamento dos sentidos da realidade. Por isso, segundo PB2, é fundamental no labor docente: "Estudar o referencial teórico, aprofundando-o, coletar os dados, relacionar arquivos com a história [...] dentro disso, você vai formando uma produçáo e chegando às produçóes, artigos".

Mas é importante ressaltar que os programas de pós-graduaçáo stricto sensu se justificam fundamentalmente pelo avanço do conhecimento e náo somente em razáo da necessidade de assimilaçáo dos procedimentos e resultados da pesquisa.

Na pós-graduaçáo, o que está em pauta é a abordagem de problemas específicos, alicerçado num empenho de fundamentaçáo teórica antecedido por um criterioso trabalho de pesquisa e reflexáo. A professora PB2 descreve esse processo da seguinte forma: "Eu levanto as questóes com as quais eu estou 
trabalhando. Mas a rotina é a mesma: leitura, releitura, organização de questöes e a aula em si. Entáo é parte docência e estudo em sentido estrito".

Todavia, apesar dessa dimensáo de anterioridade ou, ao menos, de prioridade dada à pesquisa, ao serem perguntados sobre a atividade que mais gostariam de se dedicar, os professores foram unânimes em responder que prefeririam justamente o trabalho de pesquisa. A professora PB2 revela esse desejo ao afirmar que:

Gostaria de me dedicar mais, porque considero que essa é uma escolha, você ser pesquisador é uma escolha, e pesquisador produzindo texto. Eu gostaria de me dedicar mais a ela, porque é dela que eu me alimento para as outras atividades, tanto as de orientaçáo como as de docência. Nesse sentido, gostaria de me dedicar mais às atividades de pesquisa. Teoricamente você tem uma carga-horária que é para pesquisa, mas à medida que você é atropelado pela quantidade, essa é outra questáo, eu tenho uma quantidade [...]

Como esse relato esclarece, o elemento definidor da pós-graduaçáo stricto sensu é a pesquisa, "a qual determina o objetivo a ser alcançado para o qual o ensino concorre como uma mediaçáo destinada a dispor e garantir os requisitos para o desenvolvimento da pesquisa que será a pedra de toque da formaçáo pretendida”. (SAVIANI, 2007a, p. 137). Por isso, ao aluno da pós-graduaçáo é exigência essencial a apreensáo de referências epistemológicas para que possa, pesquisando, construir o conhecimento no campo da ciência. Desse modo, o elemento central em torno do qual se deve organizar a pós-graduaçáo é a pesquisa, dado que o seu objetivo primeiro é a formaçáo do pesquisador. No entanto, o atual modelo de avaliaçáo da Capes tem priorizado alguns desafios postos à pós-graduaçáo como: "[...] a flexibilizaçáo e crescimento do sistema" (MINISTÉRIO DA EDUCAÇÁO, 2004), incorporaçáo de demandas do mercado, com a implantaçáo de em detrimento de uma sólida formaçáo pedagógica do professor universitário e futuro pesquisador.

Dada essa centralidade da pesquisa, Saviani (2007a) ressalta que a orientaçáo deve ser tratada como o problema nevrálgico do sistema de pós-graduaçáo. Se a razáo de ser da pós-graduaçáo stricto sensu é formar pesquisadores, o que supóe a experiência efetiva de pesquisa, que se objetiva 
no processo de elaboração da dissertaçáo no mestrado e da tese no doutorado, "[...] segue-se que o ponto nodal do sistema de pós-graduação reside na questáo da orientação.” (SAVIANI, 2007a, p. 158).

Nesse sentido, o processo de orientaçáo é condiçáo indispensável para que o pesquisador iniciante possa dar, com segurança, os passos essenciais para dominar a pesquisa adquirindo paulatinamente, ao fim do processo de formaçáo, a necessária autonomia intelectual. A pesquisa ao lado da orientaçáo consiste, dessa forma, no papel central do sistema de pós-graduaçáo, ou seja, elas se complementam e se interdependem, consistindo num processo dialético, no qual náo existe a supremacia de uma atividade sobre a outra. Confirmando a análise de Saviani, PP2 finaliza afirmando: "Que a gente se divide nessas três atividades, a última é a mais pesada, que é orientar".

Talvez o termo "pesada” esteja se referindo à importância da atividade no contexto em que se encontra o docente e, mais ainda, os discentes. A professora PP1, ao expor as características particulares do Programa de Pós-Graduação em que exerce a docência, relata que: "Poderia dizer com segurança que a atividade do Mestrado que mais toma tempo do docente é a orientaçâo".

Isso ocorre por motivos justificáveis, que serão expostos em outro momento. Talvez o motivo mais evidente esteja vinculado à diferença de perfil dos pós-graduandos que ingressam nos programas de universidades públicas e nos programas das universidades privadas. Por isso, ressaltando a especificidade do seu Programa, a professora PP2 revela que:

\begin{abstract}
Aqui, em muitas situaçóes o orientador senta com o mestrando para fazer esse levantamento, vai para um evento e compra o livro para o seu orientando, e por ai a fora. E a leitura, correçáo, devoluçáo; as muitas revisóes do texto da dissertaçáo também é uma atividade que toma muito tempo no caso dos alunos do nosso Programa.
\end{abstract}

Possivelmente, o professor que esteja começando seu trabalho na pós dedique maior tempo à docência porque está se organizando para trabalhar uma nova disciplina e também porque seus encargos de orientaçáo são mínimos nesses primeiros tempos. Mas, para PP1,

quem já está a mais tempo na pós e que term uma disciplina consolidada - mesmo que o professor esteja o tempo todo 
revendo a sua disciplina, trazendo novos aportes para sua disciplina, mas isso não gera maior ansiedade, náo gera maior desgaste, nem lhe consome tanto tempo. Ao que parece, a docência com todos os seus encargos náo toma tanto tempo. Eu vejo mesmo a orientaçáo, que envolve todo o trabalho de acompanhamento da produçáo da dissertaçáo como a atividade que demanda mais tempo.

Em seguida, ao lado disso, temos a produçáo, que resulta do trabalho ao longo do tempo. Na verdade, os grupos de pesquisa se consolidam também em funçáo dessa exigência cerrada de produçáo: participaçáo em evento, publicaçáo de artigo, de livros, capítulos, etc. Em tom de crítica, a professora PP1 afirma que:

Espera-se que o resultado da pesquisa se transforme rapidamente em produto. Essa é uma das razóes da tal pressão, do stress. Esse é um dos embates da pós-graduação com os órgáos de avaliação, pela intensa cobrança de produtividade, nesse ritmo em que tudo tem que gerar produto. Essa visão um pouco permeada por essa concepção tecnicista de que a produção tem que se expressar em produto... Como se isso aqui fosse um negócio a ser gerenciado de forma capitalista. Então, esse é um dos grandes fatores da pressáo sobre os professores. Agora, isso é denunciado muito mais na nossa área de Ciências Sociais e Humanas, da Educação. Na nossa avaliação, olhando as outras áreas, por exemplo, das Ciências Exatas, das áreas das Ciências Naturais e as áreas das Tecnologias, parece que isso épacifico, isso é tranquilo para os nossos colegas.

O trabalho se caracteriza sempre por sua dimensáo social, pois todas as vezes em que o indivíduo desenvolve uma atividade, inclusive a científica, mesmo que individualmente e sem uma direta associaçáo com outro ser humano, é como indivíduo que a realiza. Existir é uma atividade social e a existência uma realidade socialmente construída. Por isso, "[...] o que eu próprio produzo é para a sociedade que eu produzo e com a consciência de agir como social." (MARX, 1977, p. 140).

Apesar da importância atribuída à extensão pela pós-graduação, os critérios adotados pela política de avaliação da CAPES acabam não contemplando essa 
dimensão, da mesma maneira que contemplam a pesquisa e a produçáo. Para o professor PP3:

Todo o trabalho de extensáo acaba náo tendo lugar no Curriculo Lattes. Eu hoje produziria muito mais, de acordo com a CAPES, se deixasse de ir às aldeias e parasse as atividades que temos com as populaçóes indígenas, sentasse aqui e escrevesse. Agora que sentido tem isso? Ao mesmo tempo, contraditoriamente, se fala cada vez mais em valorizar a extensáo, a inserção dos programas de Pósgraduaçáo nas realidades regionais e tudo mais. Isso náo é avaliado. Só a produçáo mesmo. Produção, papel. Só papel. Isso eu acho que é fatal. Entáo, você tem os grandes pesquisadores, alguns que eu vejo, são produtores de papers.

Além das atividades de pesquisa, docência e orientaçáo, grande parte do tempo do professor e do grupo de pesquisa em que se insere está sendo investido na tarefa de captação de financiamentos de órgáos públicos e privados. PP1 salienta que: "Hoje o professor está ocupado com pesquisa individual e está ocupado com pesquisa em grupo. Mais uma coisa que está contribuindo para essa pressáo: o professor está cada vez mais pressionado a captar recursos externos."

Ainda que essa atividade seja importante, mais precisamente no nível local e institucional, a pressáo, revelada pela entrevistada "está vinculada ao fato de que o professor hoje, na pós-graduação, é cobrado além da atividade de docência”.

Como se percebe, a pressáo está, nesse contexto, relacionada com a intensificaçáo do trabalho docente na pós-graduação. Os professores se sentem pressionados a realizar atividades que se encontram fora daquilo que sempre caracterizou o trabalho na pós-graduaçáo, sem uma formaçáo prévia para isso. Essa atividade demanda mais esforço e mais tempo, causando uma sobrecarga física e emocional no professor, uma vez que esses projetos financiados devem igualmente ser gerenciados e, em alguns casos, pagos pelos próprios professores, visto que no geral a verba liberada náo é suficiente para pagar todas as despesas implicadas na pesquisa. Relatando isso, a professora PP2 afirma:

Que tem um projeto agora que eu estou pagando do meu bolso para uma aluna me ajudar na parte de secretaria, porque eu não tenho paciência, tem que ver os editais, tem 
que mandar e-mail, então você sai para a reuniáo e ela fica fazendo isso e eu pago do meu bolso uma ajuda para ela fazer isso. Porque se ela náo fizer eu acabo náo tendo tempo de fazer, todos nós fazemos isso, porque nos projetos você náo tem esse tipo de financiamento, até porque nem pode contratar, nos projetos é proibido contratar pessoal, às vezes você pode contratar uma assessoria técnica, por exemplo, você precisa de um estatístico, ou alguém que vai fazer filmagem, alguém para tirar foto, ou alguém que vai preparar uma coisa especifica por um periodo, mas nunca tem dinheiro que vai pegar para contratar alguém que possa secretariar, para arrumar as papeladas, cuidar de correspondência, então a gente acaba fazendo com o dinheiro da gente.

As atividades excedentes ligadas ao trabalho na pós englobam outras situaçóes. Essa relaçáo entre captaçáo de financiamentos externos e trabalho docente na pós-graduaçáo fez emergir, de forma acelerada, um movimento de "privatizaçáo da universidade pública". Náo é que a universidade se torne particular, mas ela está completamente, cada vez mais, ficando condicionada aos projetos financiados. Sobre isso reforça PP2:

Você quer um dinheirinho extra, porque você tem bolsista, quer fazer uma determinada pesquisa, você tem que aproveitar os editais de financiamento, ai você fica meio louco. Tem gente que tem vários projetos financiados para poder fazer as pesquisas que quer, para ter aluno bolsista, porque também você começa produzir e vai fazer tudo sozinho? Não dá! Você tem que ter bolsista, tem que ter grupo de pesquisa, para isso tem que ter financiamento.

Como se observa, além do gasto pessoal e da falta de apoio da instituiçáo, o professor ainda tem de administrar os recursos advindos do financiamento do projeto, fazer relatórios, arquivar material, o que demanda trabalho extra e excessivo que terá, certamente, implicaçóes contundentes na globalidade do seu trabalho na pós. A professora PB1 fez questáo de salientar que adora o trabalho que realiza: "Porque eu gosto mesmo e me sinto plenamente realizada quando estou dando aula, fazendo pesquisa e quando estou orientando. Em cada atividade dessas saio satisfeita". 
No entanto, não esconde sua insatisfação e frustração com o modo com que realiza seu trabalho dentro dessa dinâmica de intensificaçáo. Afirma o professor em questáo que:

Eu gosto de dar aula expositiva; então, é assim, eu tenho variaçáo de procedimentos didáticos, mas eu acho importante dar aulas expositivas, explicar e, para isso, eu preciso preparar aula. Então, isso demanda tempo e quanto mais atividade burocrática que a gente faz e, talvez totalmente um oposto da nossa obrigaçáo, mas por falta de funcionário a gente também acaba fazendo, menos tempo eu tenho para preparar aula, menos tempo eu tenho para me dedicar.

Novamente a relaçáo entre a pesquisa e a docência se manifesta como dimensão fundante e inseparável no trabalho na pós, mas que vem sendo afetada pelo excesso de trabalho extra que aos poucos vai ocupando espaço e se consolidando também como dimensão inseparável nesse trabalho.

Porém, existem outros fatores que estáo presentes no processo de intensificaçáo do trabalho na pós. Os dois Programas apresentam o mesmo problema de se constituírem em departamentos pequenos e, por isso, afetados pela falta de professores que auxiliem a dar conta de todo trabalho. Esse é outro ingrediente que impede os professores de se dedicarem mais àquilo que é essencial no seu trabalho: a pesquisa. Sobre o assunto, PB1 expressa que:

Como nós temos um Departamento pequeno, falta professor. Eu faço toda (toda, toda, toda) a burocracia de um programa de pós-graduaçáo, resoluçóes, instrução de serviços. Eu não sei, ninguém me explica, náo tenho funcionário para perguntar. Então, está sendo assim, está sendo um caos e isso é muito frustrante. E eu queria me dedicar mais à pesquisa. Mesmo porque eu acho, acho náo, eu sinto que quando eu tinha mais tempo para pesquisa minhas aulas eram melhores, porque eu estou estudando e o que estou estudando é inclusive para melhorar minha aula, seja na Graduaçáo seja na Pós. A pesquisa alimenta o professor de conhecimento. Se você náo tem tempo para estudar como é que vai fazer o restante?

Quando se mencionou o tema do tempo e trabalho docente, os professores entrevistados deixaram transparecer, por incrível que possa parecer, que a entrada 
na pós-graduaçáo diminuía o seu tempo de pesquisa, ainda que todos tivessem consciência que a pesquisa é a razáo de ser da pós-graduação e a obrigaçáo primeira do pesquisador. No entanto, comenta a professora PB1: "O consumo de tempo é tão grande nas atividades de graduação e pós que acaba o trabalho de pesquisa, que seria prioridade, ficando, às vezes, em segundo plano".

Para essa professora, o que mais consumia o seu tempo no triênio 20072009, era "a preparaçáo de aulas para a graduaçáo e a pós-graduação. A nossa carga de trabalho na graduaçáo eu considero alta".

Todos os professores, de modo geral, gostariam de se dedicar mais à pesquisa, porque consideram que essa é uma escolha, que ser pesquisador é uma escolha e que é dela que se alimentam para as outras atividades, tanto as de orientaçáo como as de docência. Nesse sentido, gostariam de se dedicar mais às atividades de pesquisa. Teoricamente, eles têm uma carga horária que é para pesquisa, mas à medida que sáo atropelados pela quantidade de aulas e orientaçóes não podem dedicar-se como gostariam à pesquisa. Sobre isso argumenta a professora PB2 que: "Essa é outra questão, eu tenho uma quantidade de aulas muito grande. No primeiro semestre, por exemplo, eu tinha 21 horas de aula semanais, fora as orientaçóes".

Os professores entrevistados identificam também no processo de orientaçáo uma das atividades que demanda maior tempo e preocupação, porque envolve todo o trabalho de acompanhamento da produçáo do aluno. Outra atividade inerente ao trabalho docente na pós-graduação é a produçáo do próprio pesquisador, como pontua a professora PP1:

A produçáo, que resulta do trabalho ao longo do tempo. $\mathrm{Na}$ verdade, os grupos de pesquisa se consolidam também em funçáo dessa exigência cerrada de produçáo: participaçáo em evento, publicaçáo de artigo, de livros, capitulos etc.

Esse é um dos embates da pós-graduação com os órgãos de avaliação, pela intensa cobrança de produtividade, num ritmo em que tudo tem de gerar produto. As entrevistas oferecem a possibilidade de se fazer as mais diversas interpretaçóes, pois ela é uma denúncia radical da precariedade da própria educação brasileira em todos os níveis, inclusive a superior. Contudo, a nota de avaliação dos programas atribuída pela CAPES relativiza esse dado. As entrevistas expressam uma referência ao processo de intensificação do trabalho 
do professor e também um processo de extensificaçáo, pois a necessidade de se debruçar várias vezes sobre o trabalho ultrapassa os limites de tempo e espaço de realizaçáo do trabalho na pós.

Em um tom de desabafo, a professora PP2, referindo-se a esse processo de intensificaçáo e extensificaçáo do trabalho na pós-graduaçáo, afirma que:

Realmente você também não cresce e a gente costuma dizer que está envelhecendo, porque náo dá tempo de fazer leituras novas porque tem que ler muito os trabalhos de alunos. Isso que me abate, isso me cansa! Eu acho que o que a gente conversa cansa todo mundo. Então, eu acho que a gente devia na realidade... Porque você olha os programas das Federais e Estaduais, como eles náa gastam tanto tempo com orientaçáo... O tempo de atendimento com o aluno é muito... Porque eles querem ler, querem publicar; aqui você vê e tem que ficar quieta.

A descriçáo do trabalho docente na pós-graduaçáo feita pelos próprios docentes nos ajudam a perceber como as coisas estáo intrinsecamente relacionadas. O processo de pressáo sobre o trabalho do professor vem, como reforça PP1:

De diferentes lugares e compöem esse cenário e hoje, na pósgraduação, a gente diz assim: 'ou você está inteiramente, integralmente, visceralmente, ou náo está. Não tem como estar pela metade. Neste momento eu tenho bem pouca atividade, então, vamos dizer, a minha sensaçāo é de ver os colegas ainda sujeitos a essa pressão e que foi, de certa forma, a pressáo que me levou a avaliar a vida e falar: 'náo, agora é um outro momento; eu vou parar com isso antes que eu possa sucumbir às coisas piores que viráo por aí, do ponto de vista pessoal, de saúde.

Esse relato é expressivo porque o professor que o fez se apresentou como um exemplo dos efeitos que toda essa pressáo acarreta, pois foi um período em que estava vivendo intensamente essa pressáo. 


\section{Para concluir}

A natureza em si mesma náo pode garantir a existência humana. A existência humana náo se apresenta como uma dádiva natural. Os próprios homens devem produzi-la por meio do trabalho. Isso quer dizer que o homem se faz homem; ele náo nasce homem. Ele forma-se homem. Ele deve aprender a se produzir como homem. Assim como ele deve aprender a ser homem, ele deve aprender a produzir sua própria existência. Portanto, "[...] a produçáo do homem é, ao mesmo tempo, a formaçáo do homem, isto é, um processo educativo." (SAVIANI, 2007b, p. 154). Nesse sentido, a origem da educaçáo corresponde à origem do homem.

Existe, nesse caso, uma relaçáo de identidade na relaçáo entre trabalho e educaçáo. No próprio ato de produzir a sua existência, os homens aprendiam a produzi-la. No trabalho, eles aprendiam a trabalhar. Atuando sobre a natureza, os homens se autoeducavam e educavam às novas geraçóes, relacionando-se uns com outros. Assim, como indica Saviani (2007b, p. 154), a produçáo da existência implica o desenvolvimento de formas e conteúdos que são validados pela experiência, configurando-se como um singelo processo de aprendizagem. Nesse processo, aqueles elementos validados pela experiência e confirmados pela eficácia sáo preservados e transmitidos às novas geraçóes, como forma de manutençáo e continuidade da espécie. Os que não são confirmados sáo afastados.

O trabalho docente na pós-graduaçáo, produto histórico da atividade produtiva, também precisa ser pensado com base nas determinaçóes fundamentais que sáo as relaçóes de trabalho e as relaçóes sociais de produção. Problematizar o sentido do trabalho docente na pós-graduação é problematizar, igualmente, o sentido desse ser humano concreto. Por isso, problematizar o trabalho docente na pós-graduaçáo equivale a problematizar o sentido da existência do trabalhador docente da pós-graduação. Como o trabalho se revela como um processo que permeia e confere o ser homem do próprio ser humano, constituindo, assim, sua especificidade, ele não pode ser entendido apenas, e de forma restritiva, "[...] como uma ocupaçáo, um mero fazer, um emprego, uma questáo de sobrevivência ou de ascensáo" (SILVA, 2008, p. 88). Nesse sentido, torna-se importante investigar o que os docentes têm a dizer sobre seu trabalho e de que maneira se veem e sentem nesse processo. 
Não obstante as conquistas, o sistema de avaliaçáo traz em si mesmo contradiçóes,- isto é, forças contrárias presentes no próprio modelo, capazes de gerar movimentos quer de afirmação, quer de negaçáo e de superação -, que necessitam ser discutidas e aprofundadas pela comunidade científica, objetivando náo só o aperfeiçoamento do sistema, mas também a sua adequaçáo às reais condiçōes de trabalho do professor da pós-graduaçáo.

Na década de 1990, ocorreram transformaçóes da economia capitalista, nas políticas para a educaçáo superior, afetando o trabalho docente na pósgraduaçáo, mas não na forma do Estado que ainda continuou sendo "[...] comitê para gerir os negócios de toda a classe burguesa" (MARX; ENGELS, 1983, p. 23). Carmo (2003) ressalta que a reorganizaçáo econômica nesse período tornou necessária a discussáo, entre outras, sobre a qualificaçáo da força de trabalho, do emprego e da competitividade.

A reforma conservadora do aparelho do Estado brasileiro tem, especialmente nas últimas décadas, usado a avaliação da pós-graduação como um meio de regulaçáo e controle, em meio aos ajustes ultraliberais da economia. A crise e a substituiçáo do Estado do Bem-Estar, a neoliberalizaçáo da economia, a restriçáo da esfera pública e a ampliação do polo privado incentivam a reconfiguraçáo do Estado, ao mesmo tempo que garante o crescimento do capital em detrimento da diminuiçáo dos direitos do trabalho, instrumentalizando-se da avaliaçáo da pós-graduaçáo que foi posta a serviço do poder hegemônico para regular e controlar o sistema.

Nesse cenário, manifesta-se o denominado Estado Avaliador, expressáo:

que caracteriza o Estado forte, no controle do campo social, e liberal relativamente à economia. Segundo essa lógica, o Estado confere maior liberdade à gestáo dos meios e processos, como fator de eficácia e produtividade, podendo assim justificar a diminuição dos financiamentos e criar as facilidades para a expansáo da privatização e da mentalidade empresarial da educação. (DIAS SOBRINHO, 2003, p. 139).

O "Estado Avaliador", por meio do mecanismo que chama de avaliaçáo da pós-graduaçáo, exerce um forte controle sobre fins e produtos, para solidificar os modelos pretendidos e orientar, ao mesmo tempo, o mercado. 
Assim, as atuais políticas para a educação superior do país se encontram inseridas nessa estratégia de inclusáo da economia brasileira às intensas mudanças que vêm ocorrendo na base produtiva do capitalismo em nível global. O processo de reestruturaçáo da economia trouxe como resultado a imposiçáo de um conjunto de reformas, mormente orientadas pela busca da reduçáo de gastos com as políticas sociais, atingindo, assim, também as políticas públicas para a pós-graduação.

As políticas públicas sáo estratégicas importantes para o Estado capitalista, pois, por um lado, elas manifestam as singularidades inerentes à intervençáo de um Estado comprometido e submetido aos interesses gerais do capital na ordenaçáo e na administraçáo da coisa pública, objetivando assegurar e ampliar os mecanismos de controle e de cooptaçáo social. Por outro, o Estado precisa se obrigar a se comprometer com as muitas forças sociais em confronto, se, por "definiçáo", náo se encontra à disposiçáa exclusiva de uma ou outra classe. Por conseguinte,

As políticas públicas, particularmente as de caráter social, são mediatizadas pelas lutas, pressóes e conflitos entre elas. Assim, não são estáticas ou fruto de iniciativas abstratas, mas estrategicamente empregadas no decurso dos conflitos expressando, em grande medida, a capacidade administrativa e geral para implementar decisóes do governo. (SHIROMA, MORAES, EVANGELISTA, 2004, p. 9).

É neste cenário de correlação de forças que as políticas públicas, inclusive para a pós-graduaçáo, originadas desse modelo de Estado anunciam-se e nesse embate encontram as possibilidades para implementar sua face social, "[...] em um equilíbrio instável de compromissos, empenhos e responsabilidades." (SHIROMA, MORAES, EVANGELISTA, 2004, p. 8). Nesse contexto, o Estado capitalista assume um papel intervencionista direto em todos os planos da vida social.

A reestruturaçáo produtiva, que se formaliza nas políticas públicas, caracteriza-se como um novo padrão de acumulaçáo do capital, afetando e se difundindo também no mundo do trabalho docente na pós-graduação, ainda que esse padráo seja mais significativo na produçáo de mercadorias inerentes ao mundo do trabalho industrial. Destarte, as concepçóes e as práticas relacionadas 
ao trabalho docente na pós-graduaçáo vêm sofrendo mudanças significativas como reflexo dessas políticas.

- Ainda que essas mudanças afetem significativamente o mundo do trabalho, nota-se, ao mesmo tempo, em grande parte, um processo de naturalizaçáo dessas reformas, que podem ser percebidas pelas de açóes e reaçóes, quando existem, mitigadas por parte das instituiçóes, reitorias e pró-reitorias das universidades que passaram a conviver com naturalidade com essa dinâmica, restando aos professores-pesquisadores implicados no processo a tarefa de resistir e questionar o atual modelo. Essa resistência, no entanto, apresenta-se mais tímida quando se trata de uma instituiçáo privada.

- Portanto, há uma articulaçáo entre a reestruturaçáo do sistema capitalista com o trabalho docente na pós-graduaçáo que se encontra presente na legislaçáo, nas normas e nos documentos destinados à avaliaçáo do trabalho dos docentes da pós-graduaçáo em educaçáo. As mudanças no mundo do trabalho tiveram um impacto, que náo se pode fazer desaparecer ou ignorar, marcado pela negatividade da natureza do trabalho docente, desde a crise do fordismo até os atuais modelos de acumulaçáo flexível.

- As mudanças estruturais na forma de gestáo do Estado capitalista tiveram, como náo podia ser diferente, implicaçóes para a área da educaçáo e, no caso específico, para a pós-graduaçáo, no que concerne à descentralizaçáo das açōes e à avaliaçáo dos resultados. A CAPES é a principal agência de regulaçáo da pós-graduaçáo no Brasil. Por meio dessa agência, apreendemos o conceito de regulaçáo como o processo de produçáo de regras e de orientaçáo das condutas dos atores. A compreensáo da regulaçáo inerente a essa agência permite também compreender a regulaçáo como controle, por meio do qual se busca manter o equilíbrio do sistema.

- O tema da avaliaçáo nos permitiu identificar as implicaçóes existentes entre o trabalho docente na pós-graduaçáo e a sua regulaçáo. O Estado exerce seu controle, usando o mecanismo da avaliaçáo externa, dos resultados, que ocorre em todo final de processo de avaliação, ao exigir que os programas prestem contas da sua atuaçáo, tendo como referenciais indicadores estabelecidos com base em critérios quantitativos.

- Esse modelo de avaliaçáo faz com que a prestaçáo de contas desempenhe um papel essencial nas açóes que acontecem no sistema da pós-graduaçáo, fazendo com que o trabalho docente e a gestáo da pós-graduaçáo passem 
a ser fundamentais para que os resultados possam ser atingidos. As açóes pedagógicas na pós-graduaçáo passam a ser delimitadas pela obrigaçáo de resultados, decorrentes da cultura comercial inscrita sob a égide do capital e do cuidado do Estado Avaliador.

A produçáo intelectual é fundamentalmente avaliada pela quantidade e qualidade da produçáo científica e técnica dos docentes que fazem parte do programa. A avaliaçáo da pós-graduaçáo, realizada pelo sistema CAPES, é centrada no trabalho dos docentes. As notas recebidas pelos programas estáo intimamente relacionadas com o nível de adequaçáo do trabalho dos docentes do programa às imposiçóes de perfil e produçáo científica que têm sua origem na CAPES.

O modelo de avaliação da CAPES assumiu uma lógica produtivista, pragmática e utilitarista originadas de sua vinculação com algumas agências de fomento para a pós-graduação. Por conseguinte, o resultado da avaliaçáo já náo revela os problemas dos programas, suas potencialidades e, tampouco, sua importância para a instituiçáo, para a academia e para a regiāo. $\mathrm{O}$ resultado depende de um formulário padronizado de indicadores cuja área de concentração recai diretamente sobre cada professor credenciado na pós-graduação.

O processo de transformaçáo a que a pós-graduaçáo vem sendo submetida afeta e desvaloriza o trabalho docente que perde a sua autonomia e passa a ser controlado, adequado e uniformizado segundo critérios de produtividade fundamentada na lógica racionalizadora do capital. Essas tendências vêm aprofundando o processo de rearranjo da universidade e da pós-graduação, inclusive na sua identidade e na sua relação com a sociedade brasileira.

A pós-graduaçáo perde a sua relativa autonomia em vista de uma crescente heteronomia em relaçáo à produçáo de conhecimento, agora gerida pelo setor produtivo que financia as pesquisas sob a condiçáo de que sua agenda seja cumprida. As transformaçóes pelas quais passa o trabalho docente na pós-graduaçáo são, em grande medida, impostas por essa forma da política de regulaçáo educacional que imputa à avaliaçáo um poder constrangedor e coercitivo sem precedentes.

Ocorre uma mudança objetiva na cultura acadêmica e na própria subjetividade dos professores dada a penetraçáo clara de um modo de ser empresarial na pós-graduaçáo, fazendo com que os professores se tornem competitivos e manifestem, em alguns casos, certo conformismo com o modelo 
ao naturalizarem a dinâmica do seu trabalho. Em muitos casos, porém, os professores apresentam - como revelam as entrevistas - questionamentos, resistência e uma oposiçáo clara ao atual modelo de avaliaçáo da pós-graduaçáo.

Ao se pesquisar a relaçáo entre o trabalho docente da pós-graduaçáo e a sua política de avaliação presente nos Planos, constata-se que existe um fenômeno de intensificaçáo e precarizaçáo do trabalho docente que se revela num aumento brutal da carga de trabalho que, entre outras coisas, desqualificam sua produçáo, ao restringir o tempo necessário e a autonomia para a criaçáo e a produçáo.

Nessa perspectiva, os professores assumem bem mais o aspecto de agentes ou intermediadores da pesquisa e da extensão que são, nesse contexto, concebidas como oferta de serviço a preços de mercado, "buscando recursos alternativos à sua sobrevivência, mas ao mesmo tempo, submetendo-se a critérios que lhes sáo estranhos e francamente desfavoráveis." (MORAES, 2004, p. 87). A educaçáo torna-se mercadoria mediante a introduçáo de mecanismos de mercado no gerenciamento e financiamento das práticas educacionais: "um produto a mais entre os muitos a serem consumidos." (MORAES, 2001, p. 9). Impóe-se, desse modo, à universidade e à pós-graduaçáo, uma epistemologia que náo valoriza e, tampouco, prioriza o conhecimento acadêmico, científico, teórico.

A discussão teórica, ao ser frequente e gradativamente suprimida ou relegada a segundo plano nas pesquisas educacionais, pode trazer implicaçóes sérias na própria produçáo de conhecimento da área a curto e a médio prazos. Talvez, "a causa mais imediata desta marcha a ré intelectual e teórica esteja na definiçâa e efetivação das próprias políticas educacionais, em níveis nacional e internacional." (MORAES, 2003, p. 154). Um dos exemplos mais contundentes dessa realidade se encontra na angústia e na "loucura" dos programas de pósgraduaçáo, obrigados a atender e a obedecer disciplinarmente aos critérios do sistema de acompanhamento e avaliaçáo da CAPES, de maneira especial o de cumprir os prazos cada vez mais estreitos em que mestrandos e doutorandos devem concluir suas dissertaçóes e teses, sob a ameaça de perda de bolsas de estudo dos alunos.

\section{Notas}

1 O PPGE-UCDB foi o único Programa de Pós-Graduação em Educação, no Brasil, a alcançar a nota máxima $(5,0)$ para programas que ofereciam 
apenas o Curso de Mestrado. Tal fato ocorreu no triênio de avaliaçáo da CAPES (2007-2009). Somente no ano de 2010 o PPGE-UCDB passou a oferecer o Curso de Doutorado, sendo, portanto o segundo Programa no estado de MS a oferecer Mestrado e Doutorado em Educaçáo e o único de uma instituição privado-comunitária.

2 No triênio 2007-2009 o PPGE-UFMS obteve o conceito 4 (quatro), com o oferecimento dos cursos de Mestrado e Doutorado.

3 Para os professores entrevistados da UFMS utilizou-se a sigla PB e, para os professores entrevistados da UCDB foi utilizada a sigla PP.

4 Assim assegura o artigo 207: “[...] as universidades gozam de autonomia didático-científica, administrativa e de gestáo financeira patrimonial, e obedecerão ao princípio de indissociabilidade entre ensino, pesquisa e extensão." (BRASIL, 1988).

\section{REFERÊNCIAS}

ALVES, V. M. Formação e Trabalho de Pesquisadores em Educação: um estudo dos processos de institucionalizaçáo da pesquisa em IES 'emergentes'. 2008. 308 f. Tese (Doutorado em Educaçáo) - Programa de Pós-Graduação em Educação, Centro de Ciências da Educação, Universidade Federal de Santa Catarina, Florianópolis, 2008.

BRASIL. [Constituiçāo Federal de 1988]. Constituiçáo da República Federativa do Brasil de 1988. Diário Oficial da União, Brasília, 5 out. 1988. p. 1. Texto constitucional promulgado em 5 de outubro de 1988, com as alteraçóes adotadas pelas Emendas Constitucionais n. 1/92 a 56/2007 e pelas Emendas Constitucionais de Revisão n. 1 a 6/94. Disponível em: <http://www.planalto. gov.br/ccivil_03/Constituicao/Constituiçao.htm>. Acesso em: 2 dez. 2010.

CARMO, J. C. do. Reestruturaçáo Produtiva e competência: seus desdobramentos para a educaçáo. Revista de Estudos Universitários, Sorocaba, v. 29, n. 1, p. 43-65, jun. 2003.

DIAS SOBRINHO, J. Avaliação da Educaçáo Superior: regulaçáo e emancipaçăo. In: RISTOFF, D. (Org.). Avaliação e compromisso público: a educação superior em debate. Florianópolis: Insular, 2003. 
ENGELS, F. Sobre o papel do trabalho na transformação do macaco em homem. Ediçáo Ridendo Castigat Mores. [s. 1.]: Rocket, 1999. Versão para eBook. Disponível em: <http://forumeja.org.br/br/sites/forumeja.org.br/ files/F_ANGELS.pdf>. Acesso em: 2 dez. 2010.

HELLER, A. O cotidiano e a história. Rio de Janeiro: Paz e Terra, 1970.

INFRANCA, A. Trabajo, individuo, historia: el concepto de trabajo en Lukács. Buenos Aires: Herramienta, 2005.

KOSIK, K. Dialética do concreto. 5. ed. Rio de Janeiro: Paz e Terra, 1989.

LESSA, S. História e ontologia: a questáo do trabalho. Crítica Marxista, Campinas, v. 20, p. 70-89, 2005. Disponível em: <http://www.unicamp.br/ cemarx/criticamarxista/critica20-A-lessa.pdf>. Acesso em: 6 jan. 2011.

LUKÁCS, G. Estética. 2. ed. Barcelona: Grijalbo, 1972.

LUKÁCS, G. Ontologia do ser social: os princípios ontológicos fundamentais de Marx. São Paulo: Ciências Humanas, 1979.

MARX, K.; ENGELS, F. Obras escolhidas I, II e III. Sáo Paulo: Alfa-Omega, 1983.

MARX, K. Contribuição à crítica da economia política. Sáo Paulo: Martins Fontes, 1977.

MARX, K. Manuscritos econômico-filosóficos: terceiro manuscrito. Trad. José Carlos Bruni. Sáo Paulo: Abril Cultural, 1985.

MORAES, M. C. M. de. Iluminismo às avessas como contexto da pósgraduaçáo no Brasil. Revista de Educação da Unisinos, Sáo Leopoldo, v. 5, n. 9, p. 79-101, jul./dez. 2004.

MORAES, M. C. M. de. Recuo da Teoria: dilemas na pesquisa em educaçáo. Revista Portuguesa de Educação. v. 14, n. 001 . Universidade do Minho. Braga: Portugal, 2001, p. 7-25. Disponível em: <http://www.scielo. br/pdf/rbedu/v14n41/v14n41a06.pdf>. Acesso em: 7 jan. 2011.

MORAES, M. C. M. de. (Org.). Iluminismo às Avessas: produção de conhecimento e políticas de formaçáo docente. Rio de Janeiro: DP\&A, 2003.

PESSANHA, E. C. Professor primário: ascensáo e queda de uma categoria profissional filiada às camadas médias. São Paulo: Ed. da USP, 1995. 


\section{REUNIĀO ANUAL DA ASSOCIAÇĀO NACIONAL DE PÓS-} GRADUAÇÃO E PESQUISA EM EDUCAÇĀO (ANPEd), 28., 16-19 de outubro de 2005, Caxambú, MG. 40 anos da Pós-Graduação em Educação no Brasil. Caxambu, MG: ANPED, 2005.

SILVA, M. das G. M. da. Trabalho Docente na Pós-Graduação: a lógica da produtividade em questáo. 2008. 232 f. Tese (Doutorado em Educaçáo) - Programa de Pós-Graduaçáo em Educaçáo, Universidade Federal do Rio Grande do Sul, Porto Alegre, 2008.

SAVIANI, D. A pós-graduaçáo em educaçáo no Brasil: pensando o problema da orientaçáo. In: BIANCHETTI, L.; MACHADO, A. M. N. (Org.). A bússola do escrever: desafios e estratégias na orientaçáo de teses e dissertaçóes. 2. ed. Sáo Paulo: Cortez; Florianópolis: Ed. da UFSC, 2007a.

SAVIANI, D. Trabalho e Educação: fundamentos ontológicos e históricos. Revista Brasileira de Educação, Rio de Janeiro, v. 12, n. 34, p. 152-180, jan./ abr. 2007b.

SEVERINO, A. J. A pós-graduação em educação no Brasil: caminhos percorridos e horizontes a explorar... Educaçâo \& Linguagem, Sáo Paulo, v. 12, n. 20, p. 273-293, jul./dez. 2009.

ShIROMA, E. O.; MORAES, M. C. M. de; EVANGELISTA, O. Política Educacional. 3. ed. Rio de Janeiro: DP\&A, 2004.

VÁZQUEZ, A. S. Filosofia da Praxis. 4. ed. Rio de Janeiro: Paz e Terra, 1977.

MINISTÉRIO DA EDUCAÇÃO. Coordenaçáo de Aperfeiçoamento de Pessoal de Nível Superior - CAPES. V PLANO NACIONAL DE PÓSGRADUAÇĀO (PNPG) 2005-2010. Brasília (DF), 2004. Disponível em: <http://www.capes.gov.br/sobre-a-capes/plano-nacional-de-pos-graduacao $>$. Acesso em: 2 dez. 2010. 


\section{Evaluation policies for post Política de evaluación del graduate programs and their posgrado y sus consecuencias consequences for teaching en el trabajo docente}

\begin{abstract}
This article investigates policies to evaluate graduate programs and their consequences for the work of researchers. The study was based on a qualitative approach, including a historic analysis and the realization of interviews with professors from the graduate programs in education at Federal University of Mato Grosso do Sul (UFMS) and Dom Bosco Catholic University (UCDB). The results indicate that current higher education policies in Brazil are inserted in a strategy for the inclusion of the Brazilian economy in the intense changes that are occurring in the productive base of capitalism on a global level. This is affecting public policies for graduate studies. The changes in the world of labor have had a significant impact marked by the negativity in the nature of the work of teachers in graduate studies.
\end{abstract}

Keywords: Educational policies. Evaluation of post graduate programs. Work of teaching.

\section{resumen}

En este artículo se investigan las políticas de evaluación del posgrado y sus consecuencias en el trabajo de los investigadores. Es un estudio de orden cualitativo que incluye el análisis histórico y la realización de entrevistas con profesores de los Programas de Posgrado en Educación de la Universidad Federal de Mato Grosso do Sul (UFMS) y de la Universidad Católica Dom Bosco (UCDB). Los resultados indican que las actuales políticas para la educación superior del país se encuentran inmersas en la estrategia de inclusión de la economía brasilera en los intensos cambios en la base productiva del capitalismo a nivel global, que cubren las políticas públicas para el posgrado. Los cambios en el mundo del trabajo tuvieron un impacto significativo marcado por la negatividad en la naturaleza del trabajo docente del posgrado.

Palabras clave: Política educacional. Evaluación del posgrado. Trabajo docente. 
Mariluce Bittar

E-mail: bittar@ucdb.br

Wercy Rodrigues Costa Junior

E-mail:wercyjr@yahoo.com.br

Recebido em: 13/7/2011

Versáo final recebida em: 27/9/2011

Aprovado em: 16/2/2012 